\title{
PERBEDAAN ASUPAN ENERGI, PROTEIN, LEMAK, KARBOHIDRAT DAN STATUS GIZI PADA REMAJA YANG TINGGAL DI WILAYAH PERKOTAAN DAN PEDESAAN (Studi di SMP Negeri 3 Semarang dan SMP Negeri 3 Mojogedang)
}

\author{
Dwiningsih, Adriyan Pramono*) \\ Program Studi Ilmu Gizi Fakultas Kedokteran Universitas Diponegoro \\ Jl.Dr.Sutomo No.14, Semarang, Telp (024) 8453708, Email : gizifk@undip.ac.id
}

\begin{abstract}
Background : multiple nutritional problems are not only in urban communities but also in rural communities. The prevalence of obesity of teenagers were not only in urban areas (7.8\%), but also in rural areas (2\%). This study aimed to determine differences of energy intake, protein, fat, carbohydrates and nutritional status of adolescence betwen urban and rural areas.

Method : The design of this study was a cross-sectional with the minimum number of sample for urban area 49 subjects and for rural area 45 subjects, drawn by simple random sampling method. Data included subject characteristics that were obtained from questionnaires, energy intake, protein, fat, carbohydrates were obtained from 24 hours food recall, nutritional status was obtained from the percentile charts based on the body mass index,

age, and gender. Data analysis used in this study were the Mann Whitney and independent t-test.

Result : The prevalence of overweight of adolescence in urban areas (10,2\%) was higher than in rural areas $(6,6 \%)$. Mean while, malnutrition among adolescence in rural areas $(31,1 \%)$ was higher than in urban areas $(8,2 \%)$. The average percentage of energy intake (99,4\%) was higher in urban areas than in rural areas $(96,6 \%)$. The average percentage of protein (76.6\%) was higher in urban areas than in rural areas (74.0\%). The average percentage of fat intake $(181,1 \%)$ was higher in urban areas than in rural areas $(171,8 \%)$. The average percentage of carbohydrates intake (82,5\%) was higher in rural areas than in urban areas (80,9\%). Test analysis of the differences on the two subjects resulted as follows: energy intake $(p=0.108)$, protein intake $(p=0.254)$, fat intake $(p=0.254)$, carbohydrate intake $(p=0.173)$, and nutritional status $(p=0,000)$

Conclusion : There was no difference of energy intake, protein, fat, carbohydrate of between adolescent in rural and urban areas $(p>0,05)$. There was difference nutritional status of between adolescent in rural and urban areas $(p<0,05)$
\end{abstract}

Keywords : energy intake; protein; fat; carbohydrates; nutritional status; adolescent; urban and rural area

\section{ABSTRAK}

Latar Belakang : masalah gizi ganda tidak hanya terdapat pada masyarakat perkotaan saja akan tetapi juga terdapat pada masyarakat pedesaan. Prevalensi obesitas pada remaja tidak hanya terjadi di wilayah perkotaan (7,8\%), namun juga di pedesaan (2\%). Penelitian ini bertujuan untuk mengetahui perbedaan asupan energi, protein, lemak, karbohidrat dan status gizi pada remaja yang tinggal di wilayah perkotaan dan pedesaan.

Metode : Rancangan penelitian ini adalah cross-sectional dengan jumlah sampel di kota 49 subjek dan di desa 45 subjek, diambil dengan metode simple random sampling. Data meliputi karakteristik subjek, asupan makanan diperoleh dari food recall 24 jam, status gizi diperoleh dari grafik persentil berdasarkan indeks massa tubuh, umur dan jenis kelamin. Analisis data dengan Mann-Whitney, dan independent t-test.

Hasil : Prevalensi overweight pada remaja di wilayah perkotaan $(10,2 \%)$ lebih tinggi bila dibandingkan dengan remaja di wilayah pedesaan (6,6\%). Sedangkan untuk status gizi kurang pada remaja di wilayah pedesaan (31,1\%) lebih tinggi bila dibandingkan dengan remaja wilayah perkotaan (8,2\%). Rerata persentase asupan energi di wilayah perkotaan lebih tinggi (99,4\%) dibanding di pedesaan (96,6\%). Rerata persentase protein di kota (76,9\%) lebih tinggi dibandingkan dengan desa (74,0\%). Rerata persentase asupan lemak di kota (181,1\%) lebih tinggi bila dibandingkan dengan desa (171,8\%). Rerata persentase asupan karbohidrat di desa (82,5\%) lebih tinggi bila dibandingkan dengan di kota (80,9\%). Uji analisis perbedaan kedua subyek diperoleh hasil, asupan energi ( $p=$ $0,108)$, asupan protein $(p=0,254)$, asupan lemak $(p=0,173)$, asupan karbohidrat $(p=0,173)$, status gizi ( $p=$ 0,000).

Kesimpulan : Tidak ada perbedaan asupan energi, protein, lemak dan karbohidrat pada remaja yang tinggal di wilayah perkotaan dan pedesaan $(p>0,05)$. Ada perbedaan status gizi pada remaja yang tinggal di wilayah kota dan remaja di wilayah desa $(p<0.05)$

Kata Kunci : asupan energi; protein; lemak; karbohidrat; status gizi; remaja; perkotaan dan pedesaan

\footnotetext{
${ }^{*}$ Penulis Penanggungjawab
} 


\section{PENDAHULUAN}

Modernisasi dan globalisasi sudah terjadi pada sebagian besar negara berkembang, termasuk Indonesia. ${ }^{1}$ Arus globalisasi dan konsep modernisasi turut berpengaruh terhadap perkembangan dan penerimaan makanan tradisional di masyarakat. ${ }^{2}$ Pola makan di masyarakat telah bergeser dari pola makan tradisional ke pola makan yang banyak mengandung energi, lemak, gula dan garam tetapi kurang vitamin, mineral dan serat. 2,3,4 Ketidakseimbangan antara asupan dan energi yang dikeluarkan menimbulkan masalah gizi, baik itu berupa masalah gizi lebih maupun gizi kurang. ${ }^{5}$ Masalah gizi pada remaja perlu diperhatikan karena pengaruhnya yang besar terhadap pertumbuhan dan perkembangan saat dewasa nanti. $^{6}$

Ketidakseimbangan antara makanan yang dikonsumsi dengan kebutuhan pada remaja akan menimbulkan masalah gizi kurang maupun masalah giz lebih. ${ }^{5,7}$ Kekurangan gizi pada remaja akan mengakibatkan penurunan daya tahan tubuh terhadap penyakit, meningkatkan angka penyakit (morbidiitas), mengalami pertumbuhan tidak normal (pendek), tingkat kecerdasan rendah, produktivitas rendah dan terhambatnya organ reproduksi. ${ }^{20}$ Gizi kurang pada remaja terjadi karena pola makan tidak teratur, perubahan faktor psikososial seperti pengaruh pergaulan teman sebaya dalam keseharian, pengaruh iklan maupun persepsi tentang tubuh ideal dalam pandangan remaja, kebutuhan gizi yang tinggi untuk tumbuh dengan cepat. Status gizi lebih pada remaja berdampak pada kesehatan ketika dewasa seperti: penyakit degeneratif dan kecenderungan untuk tetap obesitas pada masa dewasa. ${ }^{1,8}$

Masalah gizi lebih saat ini tidak hanya terdapat pada masyarakat perkotaan akan tetapi juga di masyarakat pedesaan, walaupun persentase obesitas pada anak diperkotaan cenderung lebih tinggi daripada di pedesaan. ${ }^{9}$ Hal ini berdasarkan penelitian pada remaja SLTP kota dan desa di Yogyakarta ditemukan kejadian obesitas 7,8\% untuk wilayah kota dan $2 \%$ untuk wilayah pedesaan. Hasil penelitian di Yogyakarta tersebut menunjukkan bahwa prevalensi obesitas di kota lebih tinggi bila di bandingkan dengan di desa. ${ }^{3}$

Penelitian yang dilakukan tahun 2007 pada remaja di SMP Negeri 3 Semarang ditemukan kejadian obesitas sebesar $6,7 \% .^{10}$ SMP Negeri 3 Semarang ini merupakan sekolah yang sebagian besar muridnya berasal dari kalangan menengah ke atas dan lokasi sekolah ini terletak di tengah kota dimana tempat-tempat jajanan mudah ditemui serta pusat perbelanjaan seperti mall dan counter-counter penjualan fast food mudah dikunjungi dan jumlahnya sangat bervariasi. ${ }^{14}$ Dilain pihak SMP Negeri 3 Mojogedang, Karanganyar merupakan sekolah menengah pertama yang terletak di daerah yang tergolong masih pedesaan. Di SMP Negeri 3 Mojogedang ini belum pernah ada yang melakukan penelitian tentang kejadan obesitas terhadap siswanya.

Penelitian ini dilakukan untuk mengetahui perbedaan asupan energi, protein, lemak, karbohidrat dan status gizi pada remaja yang tinggal di wilayah perkotaan dan pedesaan.

\section{METODE}

Penelitian ini dilaksanakan pada bulan November - Desember 2011 di SMP Negeri 3 Semarang yang mewakili wilayah kota dan SMP Negeri 3 Mojogedang mewakili sekolah di wilayah desa. Penelitian ini termasuk penelitian gizi masyarakat, bersifat observasional dengan pendekatan cross sectional. Besar sampel dalam penelitian ini dihitung dengan menggunakan rumus besar sampel uji hipotesis beda rata-rata dua kelompok independen. Dalam penelitian ini untuk wilayah kota diperoleh 49 subjek dan di desa diperoleh 45 subjek. Pengambilan subjek penelitian menggunakan simple random sampling ${ }^{11}$ dengan kriteria inklusi yaitu bersedia mengikuti penelitian, tidak sakit selama pengambilan data, berusia 13 - 15 tahun, tidak sedang menjalani program diet tertentu.

Variabel independen dalam penelitian ini adalah wilayah tempat tinggal (kota dan desa). Variabel dependen dalam penelitian ini adalah asupan energi, protein, lemak, karbohidrat dan status gizi. Data yang dikumpulkan meliputi karakteristik umum (usia, jenis kelamin, pekerjaan orang tua, jumlah anggota keluarga dalam satu rumah dan jenis-jenis konsumsi fast food) yang didapat melalui pengisian formulir kuesioner.

Lingkungan tempat tinggal didefinisikan sebagai wilayah domisili seseorang berdasarkan keadaan demografis dalam penelitian ini yaitu kota dan desa. Usia didefinisikan sebagai usia subjek dalam tahun berdasarkan tanggal lahir yang diketahui melalui identitas subjek dengan batasan usia 13 - 15 tahun.

Asupan energi, protein, lemak dan karbohidrat didefinisikan sebagai rerata asupan dari makanan dan minuman yang dikonsumsi selama penelitian yang diperoleh dengan metode 
food recall 3 x 24 jam. Asupan ini diperoleh melalui formulir food recall 3 x 24 jam kemudian data diproses menggunakan program nutrisurvey. Data jumlah asupan energi, , protein, lemak dan karbohidrat dibandingkan dengan kebutuhan setiap individu, kemudian dikategorikan menjadi : kurang $(<80 \%)$, baik $(80-100 \%)$, lebih $(>100 \%){ }^{12}$

Status gizi diperoleh berdasarkan persentil IMT. Data persentil IMT diperoleh berdasarkan indeks massa tubuh, usia dan jenis kelamin subjek. Persentil IMT menurut World Health Organization (WHO) dikategorikan menjadi: Obesitas $\geq 95$ persentil, overweight $\geq 85-<95$, normal $>5-<85$ persentil dan kurang $<5$ persentil. ${ }^{15}$.

Pekerjaan orang tua subjek baik ayah maupun ibu subjek didefinisikan sebagai mata pencaharian orang tua untuk memenuhi kebutuhan setiap anggota dalam keluarga, dalam penelitian ini meliputi PNS, pegawai swasta, buruh dan petani. Akses terhadap pangan didefinisikan sebagai asal keluarga subjek memperoleh bahan makanan untuk mencukupi kebutuhan makanan sehari-hari seluruh anggota dalam satu rumah. Konsumsi fast food didefinisikan sebagai jenis makanan yang mudah didapatkan, mudah disajikan dan praktis, fast food terdiri dari fast food lokal dan western fast food .

Analisis data dilakukan dengan menggunaka program Statistical Package for the Sosial Science (SPSS). Data primer yang dikumpulkan yaitu identitas, usia, tinggi badan, berat badan, asupan energi, protein, lemak dan karbohidrat. Uji normalitas data menggunakan Shapiro Wilk. Uji perbedaan setiap variabel menggunakan uji Independent Sampel T-test .Semua pengujian tersebut menggunakan tingkat signifikansi 0,05 .

\section{HASIL PENELITIAN}

\section{A. Karakteristik Subyek}

Penelitian ini dilakukan di SMP Negeri 3 Semarang mewakili wilayah kota dan SMP Negeri 3 Mojogedang mewakili wilayah desa. Periode waktu pengambilan data dari bulan November Desember 2011. Sampel di kota 49 subjek dan di desa 45 subjek.

Tabel 1. Karakteristik Subjek Berdasarkan Usia Subjek dan jenis kelamin

\begin{tabular}{cccccc}
\hline Variabel & \multicolumn{2}{c}{ Kota } & & Desa & Total \\
\cline { 2 - 6 } & $\mathrm{n}$ & $\%$ & $\mathrm{n}$ & $\%$ & $\mathrm{n}$ \\
\hline Usia (tahun) & 39 & 79,6 & 26 & 57,8 & 65 \\
$\mathbf{1 3}$ & 9 & 18,4 & 16 & 35,6 & 25 \\
$\mathbf{1 4}$ & 1 & 2,0 & 3 & 6,6 & 4 \\
$\mathbf{1 5}$ & & & & & \\
Jenis kelamin & 39 & 79,6 & 34 & 75,6 & 73 \\
Perempuan & 10 & 20,4 & 11 & 24,4 & 21 \\
Laki-laki & & & & & \\
\hline
\end{tabular}

Rentang usia subjek dalam penelitian ini antara 13-15 tahun, subjek usia 13 tahun dominan baik di kota $(79,6 \%)$ maupun di desa $(57,8 \%)$. Jenis kelamin dalam penelitian ini lebih dominan perempuan baik di kota $(79,6 \%)$ maupun di desa $(75,6 \%)$.

\section{B. Karakteristik Sosial Ekonomi}

Berikut ini merupakan tabel karakteristik sosial ekonomi subjek yang meliputi pekerjaan ayah, pekerjaan ibu dan jumlah anggota dalam satu keluarga.

Tabel 2. Karakteristik Sosial Ekonomi Berdasarkan pekerjaan ayah, pekerjaan ibu dan jumlah anggota dalam satu keluarga

\begin{tabular}{lccccc}
\hline Variable & Kota & & Desa & & Total \\
\cline { 2 - 6 } & $\mathrm{n}$ & $\%$ & $\mathrm{n}$ & $\%$ & $\mathrm{n}$ \\
\hline Pekerjaan ayah: & & & & & \\
$\quad$ PNS & 12 & 24,5 & 0 & 0 & 12 \\
Swasta & 26 & 53,1 & 12 & 26,7 & 38 \\
Petani & 0 & 0 & 21 & 46,7 & 21 \\
Buruh lepas & 5 & 10,2 & 10 & 22,2 & 15 \\
Lain-lain & 3 & 6,1 & 2 & 4,4 & 5 \\
\hline
\end{tabular}




\begin{tabular}{lccccc}
\hline Pekerjaan ibu: & & & & & \\
$\quad$ Ibu rumah tangga & 18 & 36,7 & 17 & 37,8 & 35 \\
PNS & 19 & 38,8 & 0 & 0 & 19 \\
Swasta & 12 & 24,5 & 12 & 26,7 & 24 \\
Petani & 0 & 0 & 10 & 22,2 & 10 \\
$\quad$ Buruh lepas & 0 & 0 & 5 & 11,1 & 5 \\
\hline Jumlah anggota keluarga & & & & & \\
$\mathbf{3 - 5}$ & 39 & 79,6 & 37 & 82,3 & 76 \\
$\mathbf{6 - 8}$ & 10 & 22,4 & 7 & 17,7 & 17 \\
$\mathbf{9 - 1 0}$ & 0 & 0 & 1 & 2,2 & 1 \\
\hline
\end{tabular}

Tabel 2 di atas diperoleh data, sebesar $24,5 \%$ ayah subjek di kota bekerja sebagai Pegawai Negeri Sipil (PNS), sedangkan di desa ayah subjek dalam penelitian ini tidak ada yang bekerja dalam sektor Pegawai Negeri. Wilayah desa pekerjaan dari ayah subjek yang dominan adalah sebagai petani $(46,7 \%)$. Pekerjaan ayah subjek di kota yang dominan adalah bekerja dalam sektor swasta, baik bekerja untuk perusahaan maupun sebagai wiraswasta.

Data pekerjaan ibu subjek di peroleh data, ibu subjek berprofesi sebagai ibu rumah tangga di kota sebesar 36,7\% dan di desa 37,8\%. Ibu subjek di kota tidak ada yang bekerja sebagai petani dan buruh lepas, sedangkan di desa ibu subjek tidak ada yang bekerja sebagai Pegawai Negeri Sipil (PNS).

Dalam penelitian ini diperoleh pula jumlah anggota keluarga yang tinggal dalam satu rumah, jumlah 3 sampai 5 orang paling dominan baik di kota $(79,6 \%)$ maupun di desa $(82,3 \%)$

\section{Karakteristik Status Gizi}

Berikut ini merupakan tabel karakteristik status gizi subjek berdasarkan jenis kelamin.

Tabel 3. Karakteristik status gizi berdasarkan jenis kelamin

\begin{tabular}{|c|c|c|c|c|c|c|c|c|c|c|}
\hline \multirow{2}{*}{\multicolumn{3}{|c|}{ Variabel }} & \multicolumn{8}{|c|}{ Status gizi } \\
\hline & & & \multicolumn{2}{|c|}{ Normal } & \multicolumn{2}{|c|}{ Overweight } & \multicolumn{2}{|c|}{ Obesitas } & \multicolumn{2}{|c|}{ Kurang } \\
\hline & & & $\mathrm{n}$ & $\%$ & $\mathrm{n}$ & $\%$ & $\mathrm{n}$ & $\%$ & $\mathrm{n}$ & $\%$ \\
\hline \multirow[t]{2}{*}{ Kota } & Jenis & Perempuan & 32 & 65,3 & 3 & 6,2 & - & - & 4 & 8,2 \\
\hline & & Laki-laki & 7 & 14,3 & 2 & 4 & 1 & 2 & - & - \\
\hline \multirow[t]{2}{*}{ Desa } & Jenis & Perempuan & 23 & 51,1 & 3 & 6,6 & - & - & 8 & 17 , \\
\hline & & Laki-laki & 5 & 11,2 & - & - & - & - & 6 & $\begin{array}{c}13, \\
3\end{array}$ \\
\hline
\end{tabular}

Hasil penelitian di kota diperoleh data, jenis kelamin perempuan sebesar 65,3\% termasuk kategori normal, sebesar 8,2\% subjek perempuan di kota termasuk dalam kategori status gizi kurang. Data status gizi subjek di desa berdasarka jenis kelamin diperoleh data, seperti halnya di wilayah kota, di desapun jenis kelamin perempuan juga mendominasi hasil penelitian, sebesar $51,1 \%$ berstatus gizi normal, 6,6 \% perempuan dalam penelitian ini masuk dalam kategori overweight dan sebesar $17,8 \%$ perempuan wilayah desa masuk dalam kategori status gizi kurang.

\section{Karakteristik Asupan Makanan}

Berikut ini merupakan nilai rerata asupan energi, asupan protein, asupan lemak dan asupan karbohidrat remaja di kota dan desa. 
Tabel 4. Nilai rerata asupan energi, asupan protein, asupan lemak dan asupan karbohidrat di kota dan desa

\begin{tabular}{lcccccc}
\hline Variabel & Perkotaan & \multicolumn{3}{c}{ Pedesaan } \\
\cline { 2 - 7 } & Rerata \pm & Min & Max & Rerata \pm & Min & Max \\
& SD & & & SD & & \\
\hline Energi (kkal) & $2363 \pm 491$ & 1403 & 3659 & $1887 \pm 411$ & 1250 & 2899 \\
Protein (gr) & $68 \pm 15$ & 39 & 97 & $54 \pm 13$ & 34 & 83 \\
Lemak (gr) & $96 \pm 28$ & 40 & 168 & $74 \pm 20$ & 32 & 103 \\
Karbohidrat & $311 \pm 65$ & 161 & 468 & $261 \pm 62$ & 152 & 403 \\
(gr) & & & & & & \\
\hline
\end{tabular}

Tabel 5. Karakteristik Asupan Makan Berdasarkan Asupan Energi, Asupan Protein, Asupan Lemak dan Asupan Karbohidrat terhadap Kecukupan Individu

\begin{tabular}{lcccc}
\hline Variabel & \multicolumn{2}{c}{ Kota } & \multicolumn{3}{c}{ Desa } \\
\cline { 2 - 5 } & $\mathrm{n}$ & $\%$ & $\mathrm{n}$ & $\%$ \\
\hline Asupan energi & & & & \\
$\quad$ Defisit & 0 & 0 & 1 & 2,2 \\
$\quad$ Kurang & 22 & 44,9 & 27 & 60 \\
$\quad$ Baik & 8 & 16,3 & 6 & 13,3 \\
$\quad$ Lebih & 19 & 38,8 & 11 & 24,5 \\
Asupan protein & & & & \\
$\quad$ Kurang & 27 & 55,1 & 40 & 88,9 \\
$\quad$ Baik & 22 & 44,9 & 5 & 11,1 \\
Asupan lemak & & & & \\
$\quad$ Baik & 0 & 0 & 5 & 11,1 \\
$\quad$ Lebih & 49 & 100 & 40 & 88,9 \\
Asupan karbohidrat & & & & \\
$\quad$ Kurang & 23 & 46,9 & 18 & 40 \\
$\quad$ Baik & 25 & 51,1 & 22 & 48,9 \\
$\quad$ Lebih & 1 & 2 & 5 & 11,1 \\
\hline
\end{tabular}

Rerata asupan energi subjek di kota (2363kkal) lebih tinggi bila di bandingkan dengan subjek di desa (1887kkal). Asupan energi remaja di kota sebesar $44,9 \%$ masih dalam kategori kurang, $38,8 \%$ asupan subjek berlebih dan sebesar $16,3 \%$ asupan subjek normal. Asupan subjek untuk wilayah desa diperoleh data sebesar $60 \%$ asupan energy subjek masih dalam kategori kurang, 24,5\% asupan subjek berlebih dan sekitar 13,3\% asupan subjek masuk dalam kategori asupan normal.

Rerata asupan protein di kota lebih tinggi (68 gram) bila dibandingkan dengan subjek di wilayah desa (54 gram). Asupan protein di wilayah kota diperoleh data sebesar $55,1 \%$ asupan subjek masih kurang dari kebutuhan dan sebesar 44,9\% asupan subjek dalam kategori normal. Asupan protein untuk wilayah desa sebesar $88,9 \%$ masih dalam kategori asupan kurang.
Rerata asupan lemak di kota lebih tinggi (96 gram) bila dibandingkan dengan subjek di wilayah desa (74 gram). Asupan lemak di wilayah kota sebesar $100 \%$ asupan subjek masuk dalam kategori berlebih. Asupan lemak subjek di desa sebesar $88,9 \%$ subjek masuk dalam kategori asupan berlebih.

Rerata asupan karbohidrat di kota lebih tinggi (311 gram) bila dibandingkan dengan subjek di wilayah desa (261 gram). Asupan karbohidrat subjek di kota sebesar 46,9\% masuk dalam kategori asupan kurang, 51,5\% asupan normal. Asupan karbohidrat di desa sebesar 48,9\% kategori asupan normal dan 40\% kategori asupan kurang.

\section{E. Karakteristik Pangan Keluarga}

Berikut ini merupakan tabel karakteristik akses pangan subjek meliputi tempat memperoleh bahan pangan dan konsumsi fast food baik fast food western maupun fast food lokal. 
Tabel 6. Karakteristik Akses Pangan Berdasarkan Tempat Memperoleh Bahan Pangan dan konsumsi fast food

\begin{tabular}{lcccc}
\hline Variable & \multicolumn{2}{c}{ Kota } & \multicolumn{2}{c}{ Desa } \\
\cline { 2 - 5 } & $\mathrm{n}$ & $\%$ & $\mathrm{n}$ & $\%$ \\
\hline Asal Bahan pangan keluarga & & & & \\
$\quad$ pasar & 19 & 38,8 & 4 & 8,9 \\
pedagang keliling & 13 & 26,5 & 19 & 42,2 \\
$\quad$ Supermarket/minimarket & 17 & 34,7 & 0 & 0 \\
$\quad$ sawah/kebun & 0 & 0 & 22 & 48,9 \\
Jajanan lokal & & & & \\
$\quad$ Mie (ayam, bakso, instan) & 20 & $40,, 8$ & 19 & 42,2 \\
Berbagai gorengan & 10 & 20,4 & 13 & 28,9 \\
Makanan ringan & 5 & 10,2 & 13 & 28,9 \\
Kue-kue & 7 & 14,3 & 0 & 0 \\
$\quad$ Nasi goreng & 7 & 14,3 & 0 & 0 \\
western fast food & & & & \\
Tidak membeli & 0 & 0 & 27 & 60 \\
Fried chicken & 29 & 59,2 & 17 & 37,8 \\
French fries & 8 & 16,3 & 0 & 0 \\
Ice cream & 10 & 20,4 & 1 & 2,2 \\
Soft drink & 2 & 4,1 & 0 & 0 \\
\hline
\end{tabular}

Bahan makanan keluarga yang diperoleh dari pasar di kota $(38,8 \%)$ dan di desa $(8,9 \%)$ pedagang keliling $(26,5 \%)$ dan minimarket $(34,7 \%)$. Sedangkan di wilayah desa $48,9 \%$ bahan makanan dalam keluarga subjek diperoleh dari kebun atau sawah dan sisanya berasal pasar $(8,9 \%)$ dan pedagang keliling (42,2\%). Karena sebesar $34,5 \%$ pekerjaan orangtua subjek di wilayah pedesaan bermata pencarian sebagai petani. Selain itu kebanyakan dari mereka memiliki lahan kosong yang bisa ditanami sayuran. Mereka menanam sayur mayur mereka sendiri, sedangkan untuk lauk pauk sebagian besar membeli dari pasar dan pedagang keliling.

Wilayah perkotaan sebesar $40,8 \%$ subjek sering mengkonsumsi mie baik itu mie ayam, bakso maupun mie instan sisanya sering mengkonsmsi berbagai jenis gorengan, nasi goreng, kue, makanan ringan. Jenis makanan lokal yang sering dikonsumsi di wilayah pedesaan juga tidak jauh berbeda dengan subjek di perkotaan yaitu sebesar $42,2 \%$ subyek sering mengkonsumsi mie sedangkan sisanya senang mengkonsumsi berbagai jenis gorengan dan makanan ringan.

Wilayah perkotaan konsumsi fried chicken lebih dominan yaitu sebayak $59,2 \%$, sedangkan untuk wilayah pedesaan sebesar $37,8 \%$ subjek juga mengkonsumsi fried chicken.

F. Uji Perbedaan Variabel pada Remaja di Kota dan Desa

Tabel 7. Analisis Rerata dan Perbedaan Beberapa Variabel Remaja di Kota Dan Desa

\begin{tabular}{lccccccc}
\hline & Perkotaan & \multicolumn{3}{c}{ Pedesaan } & p \\
\cline { 2 - 8 } & $\begin{array}{c}\text { Rerata } \pm \\
\text { SD }\end{array}$ & Min & Max & $\begin{array}{c}\text { Rerata } \pm \\
\text { SD }\end{array}$ & Min & Max & \\
& $13,22 \pm 0,47$ & 13 & 15 & $13,49 \pm 0,63$ & 13 & 15 & \\
Usia(tahun) & $99,4 \pm 9,0$ & 82,4 & 112,2 & $96,6 \pm 9,9$ & 78,8 & 119,0 & 0,108 \\
Energi(\%) & $76,9 \pm 11,6$ & 49,8 & 97,4 & $74,0 \pm 12,5$ & 52,7 & 97 & 0,254 \\
Protein (\%) & $181,1 \pm 34,4$ & 101,6 & 258 & $171,8 \pm 31,1$ & 90,5 & 246 & 0,173 \\
Lemak (\%) & $80,9 \pm 10,3$ & 57,9 & 110,7 & $82,5 \pm 14,2$ & 50,4 & 118,3 & 0,173 \\
Karbohidrat & & & & & & & \\
$(\%)$ & & & & & & & \\
Persentil imt & $49,34 \pm 29,4$ & 0,6 & 98,5 & $21,3 \pm 25,5$ & 0,2 & 87,5 & 0,000 \\
\hline
\end{tabular}


Persentase rerata asupan energi pada remaja di $\operatorname{kota}(99,4 \%)$ lebih tinggi bila di bandingkan dengan di desa $(96,6 \%)$.

Data persentase asupan energi dan persentil IMT tidak berdistribusi normal $(\mathrm{p}<0,05)$ maka untuk uji beda digunakan uji Mann-Whitney, sedangkan persentase asupan protein, lemak dan karbohidrat berdistribusi normal $(p>0,05)$ maka untuk uji beda digunakan uji independent sampel $t$ test.

Uji beda persentase asupan energi diperoleh nilai $p>0,05$, dapat disimpulkan bahwa "tidak ada perbedaan persentase asupan energi antara remaja di wilayah kota dan desa. Uji beda persentase asupan protein, lemak dan karbohidrat diperoleh nilai $p>0,05$ maka dapat diambil kesimpulan bahwa "tidak ada perbedaan persentase asupan protein, lemak dan karbohidrat antara remaja di wilayah perkotaan dan pedesaan. Data status gizi diperoleh nilai $\mathrm{p}<0,05$ sehingga dapat disimpulkan bahwa "ada perbedaan status gizi antara remaja di wilayah kota dan desa".

\section{PEMBAHASAN}

\section{A. Karakteristik Subyek}

Penelitian ini di laksanakan di dua sekolah, yaitu SMP Negeri 3 Semarang dan SMP Negeri 3 Mojogedang. SMP Negeri 3 Semarang mewakili daerah kota merupakan salah satu sekolah di kota Semarang yang terletak di pusat kota dan dekat dengan pusat perbelanjaan. SMP Negeri 3 Mojogedang sebagai perwakilan daerah desa merupakan sekolah menengah pertama yang terletak di daerah yang tergolong masih pedesaan karena sekolah ini terletak di area persawahan di wilayah perbatasan Karanganyar. Siswa di sekolah ini tidak semuanya berasal dari desa Kedung Jeruk saja, tetapi juga dari desa-desa lain yang harus ditempuh dengan kendaraan.

Karakteristik subyek di wilayah perkotaan dan pedesaan meliputi usia subyek dan jenis kelamin. Usia subyek dalam penelitian ini rentang antara 13 - 15 tahun, subyek terbanyak dari kedua wilayah berusia 13 tahun $(69,1 \%)$. Dalam penelitian ini dari kedua kelompok jumlah subyek perempuan lebih dominan yaitu sebesar 79,6\% subyek di kota dan 75,6\% subyek di desa.

Kejadian overweight dalam penelitian ini lebih tinggi di wilayah kota $(10,2 \%)$ daripada di wilayah desa $(6,6 \%)$. Kejadian overweight di kota ditemukan pada ayah yang bekerja dan ibu subjek bukan sebagai wanita karir, sedangkan di wilayah desa kejadian overweight sebesar 4,4\% ditemukan pada kedua orangtua subjek yang bekerja. Status gizi kurang dalam penelitian ini lebih tinggi di wilayah desa $(31,1 \%)$ daripada di kota $(8,2 \%)$. Hasil penelitian ini sejalan dengan penelitian Permaisih pada tahun 2003 bahwa prevalensi gizi kurang lebih tinggi di desa $(18,7 \%)$ dibandingkan di kota $(15,4 \%)$. Tempat tinggal secara tidak langsung juga berpengaruh dengan kejadian overweight maupun obesitas pada usia remaja, karena di kota akses, distribusi dan pemilihan makanan lebih banyak bila dibandingkan dengan di desa. ${ }^{5}$ Usia remaja merupakan usia dimana mereka sangat tertarik pada hal-hal baru dan sebagian besar terpengaruh dengan lingkungan sekitar dan teman sebaya. $18,19,23$

Hasil dari penelitian ini menunjukkan bahwa status gizi overweight lebih tinggi pada perempuan $(6,4 \%)$ daripada laki-laki $(2,1 \%)$. Hasil penelitian di depok tahun 2011 menunjukkan bahwa overweight pada remaja perempuan $(52,6 \%)$ lebih tinggi daripada laki-laki $(47,4 \%){ }^{21}$

\section{B. Karakteristik Sosial Ekonomi}

Karakteristik sosial ekonomi subjek dalam penelitian ini meliputi pekerjaan ayah, pekerjaan ibu dan jumlah anggota dalam keluarga yang tinggal dalam satu rumah.

Ayah subjek di wilayah kota 93,8\% bekerja dengan beberapa jenis pekerjaan diantaranya Pegawai Negeri Sipil (PNS), dalam sektor swasta dan sebagai buruh lepas. Ayah subjek di desa bekerja dalam bidang swasta baik sebagai wiraswasta maupun bekerja sebagai buruh pabrik, sebagai petani dan buruh lepas. Pekerjaan orang tua terutama dari ayah merupakan pemasukan pokok keuangan suatu keluarga.

Pekerjaan orang tua subjek berkaitan dengan pendapatan keluarga. Pendapatan memiliki peranan penting dalam memenuhi kebutuhan makanan yang diperlukan oleh anggota keluarga. Perbedaan tingkat sosial ekonomi berpengaruh terhadap pola konsumsi makan sehari-hari. Pendapatan yang tinggi biasanya mendukung seseorang untuk membeli bahan makanan dalam jumlah yang lebih dari cukup serta cenderung beralih pada bahan pangan yang lebih mahal yaitu sumber pangan hewani.

Data anggota keluarga yang tinggal dalam satu rumah baik di perkotaan maupun di pedesaan sebagian besar berjumlah 3 sampai 5 orang $(80,9 \%)$. Status gizi di kota dengan anggota keluarga 3-5 orang, 63,3\% berstatus gizi normal dan $8,2 \%$ berstatus gizi overweight. Wilayah desa sebesar 53,3\% berstatus gizi baik dan 6,6\% berstatus gizi overweight. Jumlah anggota keluarga merupakan salah satu faktor yang mempengaruhi 
asupan makan seseorang. Keluaraga dengan banyak anak dan jarak kelahiran yang cukup dekat akan lebih banyak menimbulkan masalah gizi. ${ }^{16}$

\section{Karakteristik Asupan Makanan}

Persentase asupan energi dan status gizi (persentil IMT) tidak berdistribusi normal $(\mathrm{p}<0,05)$ maka untuk uji beda digunakan uji Mann-Whitney, sedangkan persentase asupan protein, lemak dan karbohidrat berdistribusi normal $(p>0,05)$ maka untuk uji beda digunakan uji independent sampel $t$ test.

Persentase asupan energi dengan uji MannWhitney diperoleh $\mathrm{p}=0,108$. Karena nilai $\mathrm{p}>0,05$, hal tersebut menunjukkan bahwa "tidak ada perbedaan persentase asupan energi antara remaja di wilayah perkotaan dan pedesaan. Hasil penelitian dari data recall menunjukkan makanan pokok yang banyak dikonsumsi di wilayah perkotaan antara lain nasi, roti dan mie. Sedangkan untuk wilayah pedesaan makanan pokok yang sering dikonsumsi antara lain nasi dan mie instan. Jenis makanan jajanan yang sering dan banyak dikonsumsi oleh kedua subyek diantaranya mie (bakso, mie ayam, ,mie instant), berbagai jenis gorengan, nasi goreng, coklat, roti, snack, wafer dan permen. Makanan jajanan tersebut mudah didapatkan baik di kantin sekolah maupun pedagang di luar sekolah, harga makanan-makanan tersebut juga relatif terjangkau dengan uang saku subyek. Asupan energi yang tidak sesuai dengan kebutuhan tubuh baik itu berlebih maupun kurang akan mempengaruhi kondisi seseorang. ${ }^{4}$

Persentase asupan protein dengan uji independent sampel t-test, diperoleh nilai $\mathrm{p}=$ 0,254 , hal tersebut menunjukkan bahwa bahwa "tidak ada perbedaan persentase asupan protein antara remaja di wilayah perkotaan dan pedesaan". Sumber protein di perkotaan yang dikonsumsi lebih variatif bila dibandingkan dengan di pedesaan. Sumber dari hewani lebih dominan mereka konsumsi, antara lain daging ayam, telur, daging sapi, ikan serta berbagai olahannya. Sumber - sumbe protein di wilayah pedesaan yang sering dikonsumsi oleh subyek antara lain telur, ayam, tempe, tahu dan kacang-kacangan. Sumber-sumber dari nabati yang paling sering dikonsumsi di wilayah ini, sedangkan untuk sumber dari hewani sangat jarang mereka konsumsi. Hal ini disebabkan karena harga dari sumber hewani lebih mahal bila dibandingkan dengan sumber nabati. Hal ini mungkin berkaitan dengan pekerjaan orangtua mereka yang sebagian besar bermata pencarian sebagai petani, karyawan pabrik dan buruh lepas, sehingga akan berdampak pula dengan penghasilan keluarga yang pada akhirnya akan mempengaruhi daya beli keluarga tersebut terhadap bahan makanan.

Persentase asupan lemak dengan uji independent sampel t-test, diperoleh nilai $\mathrm{p}=$ 0,173 , hal tersebut menunjukkan bahwa "tidak ada perbedaan persentase asupan lemak antara remaja di wilayah perkotaan dan pedesaan". Hal ini disebabkan karena subyek di kota dan di desa sering mengkonsumsi makanan yang digoreng, ditumis, mie instan, snack dan makanan cepat saji. Sebagai simpanan, lemak merupakan cadangan energi paling besar. ${ }^{4}$

Persentase kecukapan rata-rata asupan karbohidrat di wilayah desa $(82,5 \%)$ lebih tinggi bila dibandingkan dengan di wilayah kota $(80,9 \%)$. Hasil tersebut karena subjek di wilayah desa konsumsi sumber karbohidrat lebih dominan dan untuk sumber karbohidrat terutama beras, keluarga subjek bisa menanam sendiri karena sebesar 34,5\% pekerjaan orangtua subjek di wilayah pedesaan bermata pencarian sebagai petani. Untuk menguji perbedaan persentase asupan karbohidrat diguanakn uji independent sampel t-test, diperoleh nilai $\mathrm{p}=0,173$, hal tersebut menunjukkan bahwa "tidak ada perbedaan persentase asupan karbohidrat antara remaja di wilayah perkotaan dan pedesaan". Konsumsi karbohidrat secara berlebihan tanpa disertai pengeluaran energi yang seimbang menyebabkan energi banyak tertimbun dan apabila kondisi ini berlangsung lama dapat mengakibatkan terjadinya kegemukan. ${ }^{4}$

\section{Karakteristik Pangan Keluarga}

Subjek di wilayah perkotaan memperoleh bahan makanan dalam keluarga dari pasar $(38,8 \%)$, pedagang keliling $(26,5 \%)$ dan supermarket $(34,7 \%)$. Sedangkan di wilayah pedesaan sebesar $48,9 \%$ bahan makanan dalam keluarga subyek diperoleh dari kebun atau sawah dan sisanya berasal pasar dan pedagang keliling. Karena sebesar $46,7 \%$ pekerjaan ayah dan $22,2 \%$ pekerjaan ibu subyek di wilayah pedesaan bermata pencarian sebagai petani. Selain itu sebagian besar dari mereka memiliki lahan kosong yang bisa ditanami. Mereka menanam sayur mayur sendiri, seperti daun ketela, kangkung, bayam, daun melinjo, kacang panjang, daun pepaya, sedangkan untuk lauk pauk sebagian besar membeli dari pasar dan pedagang keliling.

Dengan kemajuan informasi dan teknologi memudahkan masyarakat untuk mengakses berbagai kemudahan, termasuk dalam hal konsumsi makanan. Sebagian besar dari kita menginginkan segala sesuatu secara praktis dan 
cepat. Maka makanan siap saji menjadi pilihan untuk memenuhi kebutuhan. Dalam penenlitian ini ditemukan data di wilayah perkotaan sebesar $38,8 \%$ subyek sering mengkonsumsi mie baik itu mie ayam, bakso maupun mie instan sisanya sering mengkonsmsi berbagai jenis gorengan, nasi goreng, kue/roti, makanan ringan.

Jenis makanan lokal yang sering dikonsumsi di wilayah pedesaan juga tidak jauh berbeda dengan subyek di perkotaan yaitu sebesar $42,2 \%$ subyek sering mengkonsumsi mie sedangkan sisanya senang mengkonsumsi berbagai jenis gorengan dan makanan ringan. Data konsumsi western fast food yang sering dikonsumsi di wilayah perkotaan konsumsi fried chicken lebih dominan yaitu sebayak 59,2\%. Sedangkan untuk wilayah pedesaan sebesar $37,8 \%$ subyek juga mengkonsumsi fried chicken. Ini sedikit memberikan gambaran bahwa wilayah pedesaan sekarang sudah mengarah pada arah transisi, walaupun konsumi western fast food maupun lokal masih tinggi di wilayah perkotaan. Hal tersebut disebabkan subyek di wilayah kota lebih mudah menemukan restoran atau counter fast food yang menyediakan menu yang lebih banyak, variatif bila dibandingkan dengan di desa. ${ }^{3}$ di wilayah perkotaan tempat-tempat jajanan mudah ditemui serta pusat perbelanjaan seperti mall dan counter-counter penjualan fast food mudah dikunjungi dan jumlahnya sangat bervariasi. ${ }^{1}$

\section{KESIMPULAN}

1. Tidak ada perbedaan antara asupan energi, protein, lemak dan karbohidrat antara subjek di kota dan di desa.

2. Ada perbedaan status gizi antara subjek di kota dan di desa.

\section{DAFTAR PUSTAKA}

1. Hadi H. Beban Ganda Masalah Gizi dan Implikasinya Terhadap Kebijakan Pembangunan Kesehatan nasional. Pidato Pengukuhan Jabatan Guru Besar. FK UGM. Yogyakarta. 2005

2. Sudiarti T. Pola konsumsi makanan tradisional rumah tangga di pedesaan dan perkotaan. Bogor. IPB. 1997

3. Mahdiah. Prevalensi Obesitas dan Hubungan Konsumsi Fast Food Dengan Kejadian Obesitas Pada Remaja SLTP Kota dan Desa Di Daerah Istimewa Yogyakarta. Tesis. Program Studi Ilmu Kesehatan Masyarakat. Program Pascasarjana UGM. Yogyakarta.

4. Almatsier S. Prinsip dasar ilmu gizi. Jakarta: PT. Gramedia Pustaka Utama ; 2003.
5. Permaisih. Status gizi remaja dan faktor-faktor yang mempengaruhi. Tersedia dari: http://www. litbang.depkes.go.id.

6. Departemen Gizi dan Kesehatan Masyarakat. Gizi dan kesehatan masyarakat. FKM UI. Jakarta: Raja Grafindo Persada; 2007.hal; 234

7. Sharon RR, Kathryn P, Elie W. Weight Management: Overweight and Underweight. In: Understanding Normal and Clinical Nutrition. $7^{\text {th }}$ edition. Unites States of America: Thomson;2006.p.285

8. Nikmawati EE, Nurhayati A, Setiawati T. Analisis Perilaku Gizi Remaja untuk Pengembangan Model Pendidikan Gizi yang Berintegrasi dengan Kegiatan Sekolah. Artikel Peneitian Fundamenta. Fakultas Pendidikan Teknologi dan Kejuruan Universitas Pendidikan Indonesia. 2009.

9. Atmarita, Tinden, R. Masalah Gizi Perkotaan Di Indonesia Sudah Perlu Mendapat Perhatian: Prosiding Kongres Nasional Persagi dan Temu Ilmiah XII, 2002.

10. Rudy P. Besar Risiko Frekuensi Makan, Asupan Energi, Lemak, Serat dan Aktivitas Fisik terhadap Kejadian Obesitas pada Remaja Sekolah Menengah Pertama. Semarang: Program Studi Ilmu Gizi FK UNDIP.2007.

11. Sudigdo S, Sofyan I. Dasar-dasar metodologi penelitian klinis edisi ke-2. Jakarta: CV. Sagung Seto;2002. hal : 269

12. Widajanti L. Survey Konsumsi Gizi. BP UNDIP. Semarang. 2009.

13. Inoue, S, Zimmet P. and Caterson I. The AsiaPacific Perspective: Redefining Obesity and its treatment. Health Communication, Australia;2000.

14. Suandi IKG. Obesitas pada masa remaja, dalam: Buku ajar "tumbuh kembang remaja dan permasalahannya“. Jakarta: CV. Sagung Seto. 2004. hal: 78.

15. World Health Organization (WHO). Underweight, Short Stature and Overweight in Adolescents and Young Women in Latin America and the Caribbean. Tersedia dari: www.who.int

16. Sidartawan S. Perjalanan Obesitas menuju Diabetes dan Penyakit Kardiovaskular.Jakarta: Departemen Ilmu Penyakit Dalam FK UI;2005.

17. Kartikasari W. Perbedaan kebiasaan jajan anak obes dan tidak obes: studi di SD. Hj. Isriati Semarang [skripsi]. Semarang: Fakultas Kedokteran Universitas Diponegoro; 2006.

18. Nurhaedar Jafar. Perilaku Gizi Seimbang pada Remaja. Fakultas Kesehatan Masyarakat Universitas Hasanuddin. 2012. Tersedia dari: http://repository.unhas.ac.id

19. Dasuki. Konsumsi Lemak dan Status Gizi Remaja di Bogor. Bogor. Fakultas Pertanian Institut Pertanian Bogor; 2002.

20. Soekirman. Fortifikasi dalam Program Gizi, Apa dan Mengapa. Koalisi Fortifikasi Indonesia; 2003 
21. Ratu Ayu Dewi Sartika. Faktor Risiko Obesitas pada Anak 5-15 tahun di Indonesia. Fakultas Kesehatan Masyarakat, Universitas Indonesia, Depok. 2011: $37-43$

22. Gibson RS. Principles of Nutritional Assesment ${ }^{2 \mathrm{rd}}$ Edition. University of Otago Dunedin, New Zealand Oxford University Press 2005. P: 273-293

23. Wiwied Dwi Oktaviani, Lintang Dian Saraswati, M. Zen Rahfiludin, Hubungan Kebiasaan Konsumsi Fast Food, Aktivitas Fisik, Pola Konsumsi, Karakteristik Remaja Dan Orang Tua Dengan Indeks Massa Tubuh (IMT) (Studi Kasus pada Siswa SMA Negeri 9 Semarang Tahun 2012). Jurnal Kesehatan Masyarakat, 2012, Hal:542-553. Tersedia dari: http://ejournals1.undip.ac.id/index.php/jkm 